\title{
A ARTE COMO CONTRAPONTO À TÉCNICA MODERNA EM HEIDEGGER
}

\section{ART AS A COUNTERPOINT TO MODERN TECHNOLOGY IN HEIDEGGER}

\author{
Marina Coelho Santos ${ }^{1}$ \\ (marinacoelho95@gmail.com)
}

\begin{abstract}
RESUMO
Este artigo pretende analisar de que modo a arte, para Heidegger, mostra-se como uma manifestação do ser contrapontual ao modo de ser da técnica moderna - entendida como a época final da metafísica. Para isso, será necessário analisar a noção grega de techné e como essa noção inicialmente está vinculada tanto ao saber da produção de utensílios quanto ao saber da produção artística. Desse modo, veremos como a techné grega, entendida como um saber, transforma-se, com o predomínio da metafísica, em um fazer, desdobrando-se ao longo da história até a época da técnica moderna. A partir da consumação da metafísica na era da técnica, pretendemos mostrar, focados no ensaio A origem da obra de arte (1936), que a arte, para Heidegger, sendo ao mesmo tempo consanguínea e estranha à técnica moderna, mostra-nos uma relação mais original com o ser e com noções a ele vinculadas, como verdade e origem.
\end{abstract}

Palavras-chave: Arte. Técnica. Metafísica. Origem.

\begin{abstract}
This article intends to analyze how art, according to Heidegger, shows itself as a manifestation of being counterfactual to the mode of being of technology - understood as the final epoch of metaphysics. For this purpose, it will be necessary to analyze the Greek notion of techné, and how this notion is initially linked both to the knowledge of the production of utensils, and to the knowledge of artistic production. Thus, we will see how the Greek techné, understood as a knowledge, becomes, with the predominance of metaphysics, a doing, unfolding throughout history until the time of modern technology. In regards to the consummation of metaphysics in the age of the technology, we intend to show, focusing on the essay The Origin of the Work of Art (1936), that art, for Heidegger, being at once consanguineous and foreign to modern technique, shows us a more original relation with being and with notions attached to it, such as truth and origin.
\end{abstract}

Keywords: Art. Technology. Metaphysics. Origin.

\footnotetext{
${ }^{1}$ Mestranda em Filosofia pela Universidade Federal de Santa Catarina (UFSC).

CV Lattes: http://lattes.cnpq.br/7908472089671174.

ORCID: https://orcid.org/0000-0002-2918-9025.
} 


\section{INTRODUÇÃO}

A intenção deste artigo é apresentar de que modo arte e técnica, em sua origem, estão para Heidegger relacionadas, e de que forma a arte surge, ao fim da metafísica, como um contraponto a ser pensado em relação ao modo de ser da técnica moderna. Há no início grego uma comum pertença entre arte e técnica, na medida em que esses dois saberes são expressos pela palavra techné. Essa relação, como veremos, perde-se ao longo do desenvolvimento histórico do pensamento metafísico, que leva ao predomínio do modo de ser e agir mais afastado das origens gregas e da questão do ser, a saber, à época do predomínio da técnica moderna - diferente da techné grega. Entretanto, é justamente nesse momento culminante da tradição ocidental - na consumação da metafísica - que a relação entre arte e técnica retorna em sua questionabilidade. Na consumação da metafísica, a relação entre a obra de arte e o modo de ser da técnica moderna pode ser repensada tanto em sua origem comum quanto de forma a oferecer, a partir das interpretações de Heidegger, uma contraposição entre dois modos de se relacionar com o âmbito ontológico do ser.

De forma a contextualizar esse tema, é necessário mencionar que tal discussão se situa a partir da viravolta do pensar heideggeriano. Na viravolta, há uma preocupação não tanto com o sentido do ser a partir da analítica existencial, sentido que se revela enquanto tempo, mas uma orientação para pensar o ser a partir de sua própria história, em seu dar-se temporal. Há também nesse período uma radicalização de algo que já estava presente em Ser e Tempo (1927), a saber, a destruição dos conceitos da metafísica enquanto uma tentativa de liberação da proveniência mais original ${ }^{2}$ desses conceitos. Tal esforço de destruição se mostra, na década de 1930, como uma tentativa de superação da metafísica e, com isso, também daquilo que está implicado na metafísica tradicional, como o pensamento sobre a arte, entendido tradicionalmente como estética.

Em Contribuições à filosofia (1936-38), obra publicada postumamente em 1989, mas pertencente ao mesmo período de A origem da obra de arte (1936), Heidegger afirma:

\footnotetext{
${ }^{2} \mathrm{O}$ conceito de origem, no âmbito de $A$ origem da obra de arte, significa: "Fazer brotar algo, trazê-lo ao ser no salto instituinte a partir da proveniência da sua essência - é isso que quer dizer a palavra origem" (Heidegger, 2002, p. 84). Zarader, em seu livro Heidegger e as palavras da origem, afirma o seguinte sobre o sentido heideggeriano de origem depois da viravolta do pensar: "[...] o que se procura na posição de origem só pode manifestar-se em modo de retiro e consiste na sua própria ocultação. [...] o que só aparece como recoberto, o que só se desvela como velado, o que só começa como já derivado [...]. Sempre não captável, ainda que nunca se desvaneça na inconsistência, permanece à espera de um pensamento que lhe seja fiel: um pensamento que dê a si mesmo a tarefa de [...] meditar a diferença constitutiva da origem, sabendo embora a absoluta vanidade de qualquer pôr a nu" (Zarader, 1990, p. 354).
} 
A superação da estética, por sua vez, se revela como necessária a partir da confrontação histórica com a metafísica enquanto tal. Essa metafísica contém a posição ocidental fundamental em relação ao ente e, com isso, também o fundamento em relação à essência até aqui da arte ocidental. (HEIDEGGER, 2015, p. 487)

O questionamento de Heidegger sobre a arte acontece, então, a partir de uma visão do todo da metafísica, entendida como história do esquecimento do ser. Essa visão retrospectiva só é possível a partir da consumação da metafísica, isto é, do momento em que a pergunta pelo ser encontra-se o mais distante possível dentro do modo de pensar metafísico e, por isso mesmo, suscita um apelo de retorno àquilo que foi esquecido e restou inquestionado em sua história.

No pensamento metafísico há o predomínio do ente em seu aspecto presente em detrimento do processo que possibilita ao ente vir à presença, isto é, a verdade do ser. Esse tipo de pensamento chega a sua consumação na medida em que o predomínio do ôntico é cada vez mais autônomo, desdobrando-se na produção dos entes, na exploração da terra e na organização do mundo, de modo a interditar a pergunta pelo ser como uma futilidade para além dos limites daquilo que pode ser calculado e assegurado. Heidegger intitula a época da consumação da metafísica, em um primeiro momento, de maquinação e vivência e, em um segundo momento, de técnica.

A arte, por sua vez, encontra-se intimamente relacionada com a questão da consumação da metafísica enquanto maquinação e técnica, pois a arte e a maquinação, segundo Heidegger, têm suas raízes abscônditas na ideia de produção (poiesis), além de que, outrora na Antiguidade, tanto o saber técnico quanto a arte se chamavam techné. Como afirma Heidegger, em A questão da técnica (1953):

Outrora, não apenas a técnica trazia o nome de techné. Outrora, chamava-se também de techné o desencobrimento que levava a verdade a fulgurar em seu próprio brilho. Outrora, chamava-se também techné a pro-dução da verdade na beleza. Techné designava também a poiesis das belas-artes. (HEIDEGGER, 2001, p. 36)

A arte, ao possuir essa estranha consanguinidade à técnica, é, no entanto, uma possibilidade mais original de manifestação do ser e de relação com os entes do que o modo de ser da técnica moderna. Isso porque a técnica moderna é um desvelamento do ser há muito desvirtuado do sentido original de techné, na medida em que, orientada para a exploração dos entes disponíveis, para o controle e a organização do mundo e à 
exaustão da terra, a técnica moderna interdita a relação do homem com a verdade do ser. Isto é, a técnica moderna, guiada pela verdade enquanto adequação e certeza, está o mais distante da verdade do ser enquanto desvelamento (aletheia) e, por isso, constitui o maior perigo, pois mantém o homem afastado da origem, que possibilita o aparecer dos entes, e da pergunta por se ainda resta outra possibilidade para si mesmo - isto é, da pergunta por sua própria essência.

A arte, desse modo, é um contraponto ao mundo da técnica moderna na medida em que é vista, sob a ótica heideggeriana de desconstrução dos conceitos da metafísica, como o mais estranho em meio ao perigo extremo da técnica, que tudo domina e tudo possui. A arte, para Heidegger, é uma manifestação do ser que, em vez de explorar e desgastar os entes, revela-os em sua verdade, mantendo a tensão entre terra e mundo, velamento e desvelamento, sustentando uma abertura historial. Entretanto, antes de analisar melhor de que modo a arte se dá, para Heidegger, como uma manifestação da verdade do ser, é importante entender a origem comum de arte e técnica e seus desdobramentos epocais, que levam ao obscurecimento da relação entre ser e homem na época final da metafísica.

\section{DA PHYSIS E DA TECHNÉ À CONSUMAÇÃO DA METAFÍSICA}

A techné para os gregos, conforme Heidegger argumenta em A origem da obra de arte e também em Nietzsche I, não significava nem o fazer de utensílios nem o fazer de obras de arte, mas antes um saber relacionado à produção de utensílios e obras de arte. A techné, de acordo com Heidegger, é o modo de irrupção humana em meio à physis e, desse modo, indica sempre "o saber, a abertura do ente como tal, na forma de condução sapiente de um produzir" (HEIDEGGER, 2007, p. 75). A physis, por sua vez, é o primeiro nome grego para o ente na totalidade, que guarda de forma mais originária uma relação com a verdade enquanto aletheia, desvelamento. A physis, segundo Heidegger, "é aquilo que irrompe e vem à tona, crescendo a partir de si mesmo e sem ser impelido a nada, o que retorna a si e passa: vigência que irrompe e retorna a si” (HEIDEGGER, 2007, p. 75). A techné não é, portanto, um fazer que ao irromper ao encontro da physis a explora e domina, mas um saber que procede em função da physis e de acordo com a physis. A techné "deixa muito mais chegar o que já estava vindo à presença" (HEIDEGGER, 2007, p. 75). Nesse sentido, a techné é um pro-duzir (Hervorbringen) do ente enquanto leva do velamento ao desvelamento. Heidegger afirma em A origem da obra de arte que tanto o elaborar de utensílios quanto o elaborar 
de obras de arte são um pro-duzir em meio à physis. O pro-duzir, em seu sentido original, traz em meio à physis o ente do velamento ao desvelamento.

Entretanto, no começo (Beginn) da metafísica, com Platão e Aristóteles, a techné acaba por ser subjugada à forma (eidos) platônica e a própria physis acaba se despotencializando em virtude da compreensão do ser do ente que desponta como presença constante. Em Platão, essa mudança ocorre quando o determinante em todo acontecer do desvelamento dos entes na physis passa a ser somente o captar, reconhecer o aspecto (eidos) do ente já desvelado, aspecto esse que se torna normativo na medida em que possibilita a aparição de todos os entes sensíveis. Desse modo, afirma Werle: "Se, antes, o ente era no ser, a partir de agora predominará o ser do ente, com o que se inaugura a onto-teo-logia, o discurso que vai em busca do ente superior a determinar, a cada momento, a entidade do ente" (WERLE, 2011, p. 99) - isto é, inaugura-se a concepção metafísica de ser do ente no geral.

Nesse sentido, no início de A origem da obra de arte, Heidegger aponta para a necessidade de se desobstruir o modo convencional de como pensamos a arte. Essa desobstrução passa, principalmente, pela investigação do modo como interpretamos a noção de "coisa" tradicionalmente. Uma "coisa" nada mais é, para Heidegger, do que a concepção metafísica sobre o ente em geral. Desse modo, na conferência de 1936, ele aponta para três modos de conceber a coisidade da coisa predominantes na história da metafísica. Em primeiro lugar, a coisa é aquilo em torno do qual suas particularidades, propriedades, se reúnem - para os gregos: hypokeimenon. Essa denominação faz parte da experiência grega do ser do ente no sentido da presença - em seu caráter presente.

A partir dessa determinação da coisa no sentido aristotélico é designada a concepção ocidental de ser do ente e suas transposições ao longo da história: hypokeimenon vira subjectum na recepção latina, hypostasis vira substantia e assim por diante. A tradição apropria-se dessas palavras sem ter, contudo, a experiência grega delas, sua origem, dando início ao soterramento, ou à perda de solo, do pensamento ocidental. Essa concepção de coisa, ao longo da tradição, aplica-se não somente a coisas mas a todos os entes.

A segunda concepção de coisa apontada em A origem da obra de arte versa sobre uma coisa ser uma multiplicidade de dados sensívei; já a terceira concepção é bastante clássica e abarca as duas primeiras - trata-se da ideia de matéria e forma. Na ideia de matéria (hylé) tem-se o núcleo da coisa (hypokeimenon), como na primeira concepção, e uma afluência sensível, como na segunda. A forma (eidos, morphé) é aquilo que concede permanência e consistência a uma coisa. Esse par conceitual, para Heidegger, é o 
núcleo de todo pensar da estética e teoria da arte e está presente desde Platão e Aristóteles; todavia, para ele, esse par conceitual não é proveniente nem da coisa, nem da obra de arte, mas da noção de utensílio, ou seja, daquilo que é expressamente elaborado a partir de seu uso. Pois é a partir da serventia da coisa que se doam tanto a matéria quanto a forma - por exemplo, a matéria para fazer algo como um sapato e a forma que algo como um sapato deve ter. A ideia de matéria e forma não é, portanto, um modo originário de ser da coisa. Werle afirma:

No campo especificamente relacionado ao produzir artístico, essa subjugação da techné pela ideia se exprime no enquadramento do produzir pelas categorias da matéria e da forma, da ilé e da morphé. Nesse novo patamar, a techné acaba sendo orientada pelo registro de algo que limita (forma) e de algo que é limitado (matéria). Essa diferenciação entre matéria e forma, além de ser dirigida pela ideia, possui seu domić́lio originário na confecção do utensílio e das coisas de uso, no campo da atuação prática humana. (WERLE, 2011, p. 99)

Desse modo, percebe-se que no pensamento metafísico há um desvio da concepção mais original de techné, vinculada a um saber humano que irrompe em meio à emergência da physis, e da própria physis. Na tradição metafísica são a perspectiva da presença, hypokeimenon em Aristóteles, e igualmente a normatividade do aspecto dos entes, eidos em Platão, que se tornam centrais. Além disso, a ideia de matéria e forma, que provém, segundo Heidegger, da produção de utensílios e objetos de uso, torna-se predominante não apenas no pensamento sobre a arte, mas no pensamento sobre os entes em geral. Isso é perceptível, por exemplo, quando em Platão os artesãos estão relativamente mais próximos das formas verdadeiras do que o artista, que meramente produz uma imagem dos entes sensíveis.

Assim, na metafísica há uma ênfase maior na instrumentalidade e na serventia dos entes, que permite que a techné seja vista cada vez mais de modo instrumental como um fazer e um meio para um fim, e não mais atrelada à physis e à aletheia. É, entretanto, a partir de uma modificação interpretativa dos latinos em relação à teoria das quatro causas dos entes de Aristóteles que a ideia de produção no sentido do fazer, possibilitadora do surgimento da maquinação e da técnica moderna, irá se consolidar de forma mais definitiva. Isso ocorre pois no mundo romano e cristão há uma centralidade da causa eficiente aristotélica na medida em que a energeia transforma-se em actualitas, esta última entendida como realidade efetiva da qual o objeto primário é um Deus criador que é causa de si mesmo e de todos os entes. A ideia de matéria e forma também está presente aqui, conforme afirma 
Heidegger em Origem da obra de arte, uma vez que os entes são concebidos como entes criados, ou melhor, confeccionados por um Deus criador. O caminho está aberto para que, na modernidade, o sujeito assuma a condição de objeto ontológico primeiro que representa todos os outros entes e, em seu estágio final, o destino do ser se mostre como maquinação e técnica. Assim, Heidegger afirma, numa citação longa porém válida para elucidação, nas Contribuições:

O conceito medieval de actus encobre já a essência inicialmente grega da interpretação da entidade. Está em conexão com isso o fato de que, então, o elemento maquinal se impõe mais claramente e, por meio da inserção em jogo da ideia judaico-cristã da criação e da representação correspondente de Deus, o ens se transforma em ens creatum. Ainda que uma interpretação tosca da ideia de criação fracasse, permanece de qualquer modo essencialmente o ser causado do ente. O nexo causa e efeito se transforma no nexo que a tudo domina (Deus como causa sui). Isso é um distanciamento essencial da physis e, ao mesmo tempo, a passagem para o vir à tona da maquinação como a essência da entidade no pensamento moderno. (HEIDEGGER, 2015, p. 125)

A maquinação (Machenshaft), palavra derivada do verbo fazer (machen), é o estágio

final dessas modificações complexas que não podemos abordar em detalhes aqui. A maquinação é a autonomização das estruturas produtivas da realidade entendida como realidade efetiva, ou seja, determinada pelo princípio de causa e efeito, em que o que ocorre é o controle dos entes através do "cálculo, utilização, cultivo, maneabilidade e regulação" (HEIDEGGER, 2015, p. 123). De modo conjunto à maquinação, o âmbito do sujeito é designado pela vivência, ou seja, por representações do ente que se referem à percepção sensível de um sujeito representante e estão vinculadas à ideia de vida. A vida e a vivência, no entanto, encontram-se totalmente mobilizadas pela maquinação. Em verdade, maquinação e vivência são o mesmo, assim como o par objetividade-subjetividade, para Heidegger.

A técnica moderna, por sua vez, diferente da maquinação, já não aborda os entes como objetos, mas como entes disponíveis que não estão somente presentes à vista, mas à disposição para domínio, exploração e armazenamento. A técnica moderna não está sob o controle do homem, não depende exclusivamente do fazer e da vontade humana, e sua atuação se dá no mais das vezes de forma violenta e aniquiladora. Desse modo, Heidegger denomina Gestell o modo de ser da técnica, que significa composição ou articulação de todos os entes sobre os quais a técnica impõe seu posicionamento e dispõe do homem e da natureza incondicionadamente. 
Ora, a arte na época da consumação da metafísica, segundo Heidegger, caracteriza-se por ser a expressão de "vivências", de modo que Heidegger afirma, em A origem da obra de arte:

Será que a arte moderna tira proveito daquilo que tem o caráter de vivência? Ou limita-se a substituir aquilo que é vivenciado, de modo que, certamente, o vivenciar se torna agora ainda mais subjetivo do que até aqui? $\mathrm{O}$ vivenciado torna-se agora - "o que há de tecnológico no impulso criativo" ele mesmo - o "como" do fazer e do inventar. (HEIDEGGER, 1998, p. 85)

Desse modo, na época da consumação da metafísica, a arte é um ponto nodal para o projeto de destruição da metafísica em Heidegger por dois motivos. Primeiro porque a arte encontra-se também determinada pela concepção metafísica dos entes e seu destino depende igualmente de que se pense de forma mais original sua essência, isto é, o modo como a arte se dá. Essa concepção metafísica dos entes, como vimos, parte de um desvio não só do sentido de physis, mas de techné - que na aurora grega também significava o saber artístico e artesanal - para uma predominância do fazer prático e produtivo, seja através da concepção platônica de matéria e forma, seja a partir do predomínio da causa eficiente aristotélica e seu destino final na maquinação. O segundo motivo é que a arte é ela mesma, nos primórdios, como vimos, consanguínea à técnica moderna e, por isso, sua essência é para a técnica aquilo que lhe pode ser mais estranho, isto é, a arte pode constituir um contraponto à técnica no que diz respeito a sua relação com os entes e com a verdade do ser. No entanto, tanto a arte como a técnica moderna, nesse sentido, configuram modos de desvelamento do ser, como aponta Werle:

Se, na arte, o homem se ex-põe à terra e ao mundo, na técnica, ele pretende antes se im-por, embora acabe inevitavelmente também se ex-pondo, mas de uma maneira bastante perigosa, pois a técnica [...] consiste numa quebra da irrupção da physis e numa agressão à natureza. (WERLE, 2011, p. 98)

A palavra "desvelamento" em Heidegger aponta para a palavra grega aletheia e constitui o modo originário de como a verdade acontece. Sendo assim, de que modo a verdade acontece na obra de arte? Neste momento analisaremos de que modo a obra de arte, a partir do olhar "desconstrutivo" de Heidegger, revela o ser e noções a ele vinculadas, como verdade e história, de modo mais originário. 


\section{A ARTE COMO CONTRAPONTO À TÉCNICA MODERNA}

Em um primeiro momento, em A origem da obra de arte, Heidegger analisa um quadro de Van Gogh que mostra os sapatos de um camponês. A partir da arte, isto é, do quadro de Van Gogh, revela-se um ente - no caso, um sapato, um utensílio - mais propriamente em seu ser. O modo de ser do utensílio, pela arte, revela-se para além do aspecto da serventia e do uso. Segundo Heidegger, o que os sapatos do camponês revelam não é um imitação malfadada de um objeto de uso, mas o próprio ser dos utensílios, para além da determinação metafísica de matéria e forma e da percepção dos objetos a partir de sua serventia. Nesse sentido, a arte permite um acesso mais direto à verdade dos entes, ou seja, aos entes em seu ser.

Heidegger denomina a essência do utensílio como fiabilidade (Verlässlichkeit). O filósofo afirma: "Em virtude dela [da fiabilidade], a camponesa é inserida no chamamento silencioso da terra; em virtude da fiabilidade do utensílio, ela está certa do seu mundo" (HEIDEGGER, 1998, p. 29). A fiabilidade, ser do utensílio, reúne em si todas as coisas, e a serventia não é senão apenas uma consequência do modo de ser mais essencial do utensílio. Segundo o filósofo, o utensílio é usado e desgastado; o próprio usar é entendido de modo habitual, e não mais a partir da essência do utensílio, de sua fiabilidade. O utensílio, na serventia, vira mero utensílio, e assim a fiabilidade, sua essência, desvanece. Quando só a crua serventia é visível, abre-se espaço para se ver o utensílio a partir do par conceitual matéria e forma.

Nesse sentido, é só pela obra que a essência, o ser do utensílio se mostra de modo expresso. Se a obra mostra mais verdadeiramente o modo de ser de algo, o que está em obra na obra é um acontecer da verdade. Na obra, o ente, o par de sapatos, sai para o desvelamento (aletheia) de seu ser. A obra de arte revela-se, portanto, como um pôr-em-obra da verdade, de modo que a arte traz o ente à luz de seu ser. O objeto produzido para o uso, de outro modo, oculta a abertura do ser e obscurece as outras possibilidades além do utensílio que a obra revela. A arte, portanto, é espaço de abertura para que os entes saiam de seus sentidos usuais e apareçam em seu ser, de modo que resistam à subjugação pelo controle e pela familiaridade.

$\mathrm{Na}$ interpretação de Heidegger sobre a verdade da arte, não é a noção tradicional de verdade como adequação e correção que está atuando, mas um modo mais originário de pensar a essência da verdade, pois a verdade proposicional pressupõe a verdade enquanto desvelamento, e é esse sentido de verdade, enquanto modo de dar-se 
temporal do ser, que foi esquecido em virtude do ente enquanto presença. No entanto, em $A$ origem da obra de arte, a verdade enquanto desvelamento não é somente aquilo que é anterior e possibilita a verdade proposicional, mas mostra-se também como um acontecer (geschehen) histórico.

A obra de arte enquanto um acontecer da verdade, no entanto, aparece de modo exemplar na interpretação de Heidegger sobre o templo grego, uma obra não figurativa que não pode ser facilmente associada aos regimes da imitação e da representação. A interpretação do templo grego marca também de forma mais evidente, na obra de Heidegger, a mudança efetuada na viravolta do pensar, ou seja, de um pensamento do ser que deixa de estar somente focado na analítica existencial, em que o tempo diz respeito ao ser do Dasein, e passa a ser pensado em seu acontecer temporal, isto é, histórico. Trata-se de uma interpretação mais original da história da metafísica e dos diversos envios do ser que configuram épocas.

O templo grego, portanto, abre conjunturas e contextos para um povo histórico e faz tudo que está à sua volta aparecer de maneira mais essencial. Desse modo, a obra funda um mundo histórico sobre a terra a qual os homens habitam. Segundo Heidegger, a terra "é aquilo em que se volta a pôr a coberto o irromper de tudo aquilo que irrompe" (HEIDEGGER, 1998, p. 39). Aquilo que irrompe é o que os gregos chamavam de physis. A terra, portanto, é onde o homem funda seu habitar histórico. A terra é o elemento que resiste e se retrai, mas é sobretudo a obra de arte que permite que a terra adentre o mundo e se mostre, surja como tal, pela primeira vez. A obra não desgasta a terra, a matéria sobre a qual funda um mundo, mas faz com que ela surja como terra, como elemento inexplicável e resistente em tensão no aberto de um mundo, desdobrando-se na "plenitude inesgotável de modos e figuras simples" (HEIDEGGER, 1998, p. 46). O mundo, por sua vez, não é um objeto, não é a totalidade de coisas que pertencem ao mundo; o mundo também não é, como era em Ser e Tempo, o horizonte de significação do ser-aí, mas é "a abertura que se abre das longas vias das decisões simples e essenciais do destino de um povo histórico" (HEIDEGGER, 1998, p. 47). Desse modo, o mundo que a obra de arte abre é um acontecimento histórico.

Se a técnica moderna acontece de modo que o mundo subjuga a terra pela exploração até a exaustão, e é ele mesmo submetido à verdade como certeza e ao controle e organização absoluto dos entes que aí se dão, na obra de arte, de outro modo, há uma tensão, um combate entre mundo e terra que resguarda o caráter de velamento-desvelamento da verdade do ser. A obra de arte sempre mantém e revela o jogo de velamento-desvelamento, "um mostrar-se que é, ao mesmo tempo, retração. Ignorar esse caráter retrátil e 
inacabado do mostrar-se do ser é o perigo do predomínio do ente sobre o ser" (WU, 2006, p. 178). A obra, ao revelar o combate terra $x$ mundo, permanece na diferença ontológica entre ser e ente, pois o combate pertence ao aberto da verdade enquanto velamento-desvelamento. Sobre a verdade da obra de arte, Duarte afirma:

Um dos modos fundamentais em que a verdade acontece é o ser-obra da obra de arte, no qual o combate entre instauração de mundo e elaboração da terra abre o domínio histórico do desvelamento do ente na totalidade em cada época do ser. A verdade enquanto clareira do desvelamento tende a manifestar-se por meio da arte na medida em que ali onde há obra, isto é, onde há criação, vem a ser um ente determinado que põe e sustenta o aberto no qual todos os demais entes podem aparecer como desencobertos, garantindo-se a permanência e a vigência de uma dada abertura historial. (DUARTE, 2008, p. 8)

O tornar-se obra da obra é um modo do acontecer da verdade, isto é, o antagonismo entre clareira e encobrimento em que algo como um ente estabelece-se no aberto em que esse antagonismo acontece. Esse acontecimento é histórico e pode se dar, segundo Heidegger, de múltiplos modos. Pôr-se em obra da verdade, na arte, é um deles; outro é a fundação de um Estado; ainda, outro modo de a verdade vir-a-ser é o perguntar do pensador pelo ser do ente ou, no caso de Heidegger, pela verdade do ser, que nomeia aquilo que é digno de questão. Heidegger afirma: "é porque faz parte da essência da verdade estabelecer-se no ente para só então chegar a ser verdade, que no estar-a-ser (essência) da verdade há a tensão para a obra" (HEIDEGGER, 1998, p. 64). O estabelecimento da verdade na obra é o produzir de um ente que antes ainda não era e que, posteriormente, nunca mais virá a ser. Heidegger afirma: “Aí onde a produção trouxer expressamente [consigo] a abertura do ente - a verdade -, o produzido é uma obra [de arte]. Tal produzir é criar" (HEIDEGGER, 1998, p. 65).

A verdade enquanto combate de mundo e terra torna-se manifesta num ente quando esse ente é trazido ao traço-fenda (Riss) no sentido de desenhar, fender, uma forma num material. Assim, fender a matéria, traçar uma forma, é a manifestação da tensão desse combate e, ao mesmo tempo, sua união. Diz Heidegger: "o combate trazido ao traço-fenda [...] é a figura (Gestalt)" (HEIDEGGER, 1998, p. 67). O ser criado da obra significa o ser fixado da verdade na figura. Esse criar se revela, portanto, bastante diferente da produção técnica moderna. Na criação da obra de arte o combate entre mundo e terra se revela na figura e retorna à terra, pois ela é sempre liberta para si mesma, ao contrário da técnica, que dispõe e submete a terra ao domínio total para exploração. Desse modo, Werle 
elucida uma importante diferença entre o modo de ser da obra de arte e o modo de ser da técnica:

\begin{abstract}
E assim temos um forte contraste entre dois tipos de procedimentos e atitudes: uma situação é constituída pela terra como her-stellen e o mundo como auf-stellen, que estão em combate (Streif) na obra de arte e permitem o traço (Riss) enquanto forma (Gestalt). Outra situação é o impulso desafiador, extrativista e armazenador da técnica moderna como armação (Gestell). No caso do mundo e da terra, na arte, não se trata de comandar o pôr, como na técnica moderna, mas em deixar que algo se ponha por meio de um movimento mais amplo. (WERLE, 2011, p. 102)
\end{abstract}

A técnica moderna se encontra comprometida com a metafísica, como vimos, enquanto a arte revela um modo mais originário de experimentar o mundo e um modo não violento de se relacionar com os entes. Além disso, quando voltamos aos primórdios da consanguinidade da técnica e da arte, sabemos que tanto um utensílio servil - techné predominante na metafísica - quanto uma obra de arte provêm da ideia de produção, isto é, ambos são criações. No entanto, na produção de utensílios, o fato de um ente ter sido produzido se perde na serventia e no desgaste do uso, enquanto na obra de arte não predomina o seu "para quê" foi produzida, nem o "por quem", mas o fato de que a obra "é". O fato de que a obra de arte é sobressai-se em relação, por exemplo, ao fato de que um utensílio, algo também criado, é. O fato de que o utensílio é dissipa-se na serventia; o utensílio é algo habitual. Já a obra de arte, o fato de que a obra de arte é, é algo inabitual, que produz um abalo em nossas significações comuns. A obra de arte nos insere nessa abertura do ente que ela instaura e, desse modo, faz-nos sair daquilo que é habitual. A obra de arte instaura uma outra dimensão para experienciar o mundo.

Seguir essa remoção do habitual, diz Heidegger, "significa: modificar as conexões habituais com o mundo e com a terra e, desde então, reter em si as relações usuais com o fazer e apreciar, com o conhecer e o olhar, para permanecer na verdade que acontece na obra" (HEIDEGGER, 1998, p. 70). Deixar a obra ser obra, para Heidegger, é resguardar. Resguardar a obra é insistência na verdade, a insistência no combate entre terra e mundo e na remoção para o âmbito inabitual aberto pela obra. Como afirma Duarte, resguardar é "ser levado pela obra a um lugar extraordinário em que antes não se esteve, é ser exposto à ameaça do historialmente novo" (DUARTE, 2008, p. 8). Ora, o mais estranho e inabitual, para Heidegger, é o ser. A obra de arte, dessa forma, instaura a clareira, a abertura, em que o ser se manifesta historialmente. É por isso que a obra de arte é também a 
irrupção do historialmente novo, não por uma dialética ou por um progresso histórico-causal, mas a partir de uma ruptura e de uma abertura historial do ser. No entanto, pode a arte ser a instauração de uma nova época histórica para além da técnica moderna?

A técnica moderna, para Heidegger, aponta o crescimento do perigo do mesmo modo que abriga a salvação, conforme os versos de Hölderlin. Isso ocorre pois o maior perigo consiste na perda da essência do homem em meio à violência destrutiva do mundo dos entes e no esquecimento completo da questão da verdade do ser, isto é, da possibilidade de se abrir outro modo de relação com os entes. Entretanto, a técnica, como ápice do esquecimento do ser, pode revelar a indigência que impele à questão do ser. No mundo da técnica moderna, o ser, retraído, ou pode ser completamente esquecido, ou seu velamento pode se mostrar como uma face de sua verdade enquanto desvelamento.

Para Heidegger, no entanto, é o poeta aquele mais capaz de trazer pela palavra a verdade do ser, assim como o filósofo vindouro, se seu dizer é um dizer também poético. É por isso que há uma insistência maior do filósofo alemão em pensar a poesia de Hölderlin como possibilidade de, pela palavra poética, estar mais na proximidade do ser do que a partir de outros tipos de arte. No entanto, em A origem da obra de arte, Heidegger afirma que a essência da obra de arte é ela mesma poesia (Dichtung). A poesia provém de poiesis, produção, que conduz do velamento ao desvelamento. A técnica moderna também em sua essência é um desvelamento do ser, mas o modo de ser da técnica encontra-se o mais distante do sentido de aletheia e de poiesis, pois rompe com a poiesis na medida em que a técnica não é uma pro-dução em consonância com a irrupção da physis, mas um dispor para a exploração.

Sendo assim, Heidegger dirige-se para a essência da poesia como algo digno de questão no que diz respeito à essência da arte, pois a essência da arte é poética. Ao nomear os entes, a linguagem traz o ente ao aberto pela primeira vez; desse modo, o ente se mostra na palavra, na palavra ele é designado para seu ser. Heidegger diz: "O dizer projectante é poesia (ditado poético): a saga do mundo e da terra" (HEIDEGGER, 1998, p. 79). A poesia, enquanto essência da arte, enquanto aquilo que se situa no combate entre mundo e terra, institui verdade:

A essência da arte é o ditado poético. Mas a essência do ditado poético é instituição (Stiftung) da verdade. Compreendemos aqui o instituir num triplo sentido: instituir como doar (Schenken), instituir como fundar (Gründen) e instituir como iniciar (Anfangen). (HEIDEGGER, 1998, p. 80) 
A palavra início (Anfang) diz respeito à experiência originária do ser que se destina historialmente (Geschichte). Nesse sentido, a arte é uma origem na medida em que instaura historialmente a verdade do ser, enquanto desvelamento-velamento, e faz brotar o ente em sua essência, iniciando, assim, uma nova época histórica. A arte, porque institui verdade a partir desse abalo das significações ônticas e expõe o homem ao extraordinário da doação do ser, ao fundo ontológico que a obra resguarda, rompe com o habitual e inicia algo novo:

\begin{abstract}
A arte enquanto ditado poético é instituição [...] como início. Sempre que o ente no seu todo, enquanto ente ele mesmo, requer a fundamentação na abertura, a arte chega à sua essência enquanto instituição. Foi no mundo grego que ela aconteceu pela primeira vez no Ocidente. Aquilo a que daí para diante se veio a chamar "ser" foi posto em obra de forma paradigmática. $\mathrm{O}$ ente assim tornado originariamente patente no seu todo foi depois transformado em ente no sentido do criado por Deus. Isso aconteceu na Idade Média. Este ente foi de novo transformado no começo e no curso da modernidade. $\mathrm{O}$ ente tornou-se em objecto susceptível de ser dominado e decifrado por meio do cálculo. De cada vez, irrompeu um mundo novo e essencial. De cada vez, a abertura do ente teve de ser estabelecida no ente ele mesmo mediante a fixação da verdade na figura. De cada vez, aconteceu o não-estar-encoberto do ente. Este põe-se em obra, e é a arte que consuma esse "pôr". (HEIDEGGER, 1998, p. 82)
\end{abstract}

A arte, portanto, instaura mundos históricos. Sempre que o ser acontece em cada época histórica, a arte instaura a verdade no ente - isto é, a arte é uma abertura para o acontecer historial do ser. Entretanto, a questão de Heidegger é: em nosso tempo a arte pode ainda ser uma origem? Ou seja, se na medida em que nos encontramos mergulhados no modo de ser da técnica moderna e na utilização metafísica de conceitos para pensar a essência da arte e a essência da técnica, pode a arte ter o potencial de iniciar uma nova época? Em nosso entender e de acordo com Wu (2006) e Duarte (2008), Heidegger, principalmente em sua obra Contribuições à filosofia, entende a insuficiência de se pensar a história "sob o signo da instauração de novos começos" (DUARTE, 2008, p. 14), pois a instauração de novos mundos históricos permanece ainda no mesmo destino metafísico do ser. A partir das Contribuições, é necessário pensar não somente uma nova época histórica, mas pensar radicalmente um outro início para o pensamento, isto é, uma superação da metafísica. A arte, contudo, não é excluída dessa tentativa; pelo contrário, o pensamento de Heidegger se encaminha cada vez mais para um pensar poetizante e para próximo da poesia de Hölderlin. Desse modo, a necessidade de se pensar a essência da arte enquanto dizer poético (Dichtung) e como uma origem, juntamente com a essência da técnica, permanece e é evocada em A questão da técnica, como vimos, enfatizando-se o papel da arte nessa tarefa ontológica. 


\section{CONSIDERAÇÕES FINAIS}

Muitas questões ainda restam e devem ficar em aberto, como o caminho do pensamento que Heidegger traçou. Não se tratou neste artigo de argumentar sobre a superação da era da técnica através da arte, mas de mostrar como a arte, a partir de Heidegger, constitui um contraponto ao modo de ser da técnica. Para isso, foi necessário mostrar a origem comum da técnica e da arte na Antiguidade, tendo sua raiz comum na techné grega. Além disso, foi necessário mostrar como, para Heidegger, no fim da metafísica a arte, interpretada originalmente, revela um outro modo de relação com o ser, contrastando com a técnica moderna. A arte, a partir do olhar heideggeriano, é uma origem, pois põe-em-obra a verdade do ser historialmente e mostra os entes de modo mais essencial.

Vimos, portanto, a questão da arte muito mais ligada à questão ontológica do que a exemplos artísticos. Entretanto, pensamos que a ontologia revela originalmente a questão da arte e a arte revela a questão ontológica - a questão da arte dificilmente pode ser pensada sem recorrer a questões ontológicas e, como Heidegger deixou claro, a ontologia também não deve ser pensada sem recorrer à manifestação essencial da obra de arte.

No entanto, para Heidegger, que arte pode ser uma origem? Somente a grande arte? Sim e não. Ao longo de sua obra, o filósofo se atém tanto à tragédia e à escultura gregas quanto a poetas mais contemporâneos, como Trakl, Rilke, Georg, assim como o menos contemporâneo Hölderlin. Nesse sentido, seguindo o raciocínio de Vattimo (2008) em seu interessante estudo sobre a vocação ontológica das poéticas do século XX, podemos pensar ontologicamente as artes moderna e contemporânea numa abordagem heideggeriana, levando em conta a arte menos como um ponto de chegada, como em Hegel, e mais como um ponto de partida - um ponto de partida no sentido profético heideggeriano, em que o filósofo alemão se pergunta se a arte ainda pode ser uma origem. Desse modo, a arte torna-se profecia de um novo mundo, um mundo que rompe com o sistema de significações vigentes e que possamos habitar poeticamente. Apesar do termo "mundo da imaginação" não ser pertinente na discussão heideggeriana, eu gostaria de encerrar este artigo com uma citação do dadaísta Kurt Schwitters, que, por analogia, expressa o potencial da arte de construir mundos em que se possa poeticamente habitar:

Então, Helma disse: 
- Eu estou com medo!

Eu respondi:

- Você não precisa de jeito nenhum ter medo. No mundo da imaginação, eu farei para nós uma construção e nós nos mudaremos para lá. (SCHWITTERS, 2013, p. 116) 


\section{REFERÊNCIAS BIBLIOGRÁFICAS}

DUARTE, André. Heidegger e a obra de arte como acontecimento historial-político. In: Artefilosofia. Ouro Preto, n. 5, 2008. p. 23-34.

HEIDEGGER, Martin. Contribuições à filosofia: do acontecimento apropriador. Trad. Marco Antônio Casanova. Rio de Janeiro: Via Verita, 2015.

- Nietzsche I. Trad. Marco Antônio Casanova. Rio de Janeiro: Forense Universitária, 2007.

. Origem da obra de arte. In: Caminhos de floresta. Trad. Irene Borges-

Duarte e Filipa Pedroso. Lisboa: Fundação Calouste Gulbenkian, 1998.

A questão da técnica. In: Ensaios e conferências. Trad. Emmanuel

Carneiro Leão. Petrópolis: Vozes, 2001.

SCHWITTERS, Kurt. Contos Mércio. Trad. Maria Aparecida Barbosa. EDUFSC, 2013.

VATTIMO, Gianni. The ontological vocation of twentieth-century poetics. In:

Art's claim to truth. Trad. Luca D'Isanto. Nova York: Columbia University Press, 2008.

WERLE, Marco Aurélio. Heidegger e a produção técnica e artística da natureza. Trans/Form/Ação, Marília, v. 34, 2011. p. 95-108.

WU, Roberto. Heidegger e a possibilidade do novo. Rio de Janeiro. 265. [Tese (doutorado)]. PUC-RJ, 2006.

ZARADER, Marlène. Heidegger e as palavras da origem. Trad. João Duarte. Lisboa: Instituto Piaget, 1990. 